\title{
The Macquenoise sandstone (Devonian - Lochkovian), a suitable raw material for ancient querns and millstones: quarries, properties, manufacture and distribution in France and Belgium
}

\author{
Paul PICAVET ${ }^{1 *}$, Sibrecht RENIERE ${ }^{2}$, Veerle CNUDDE $^{3}$, Wim DE CLERCQ ${ }^{4}$, Roland DREESEN $^{5}$, Gilles FRONTEAU $^{*}$,
} ERIC GOEMAERE ${ }^{7} \&$ ELSE HARTOCH ${ }^{8}$

\begin{abstract}
${ }^{1}$ Univ. Lille, CNRS, Ministère de la Culture et de la Communication, UMR 8164 - HALMA - Histoire Archéologie Littérature des Mondes Anciens, F-59000 Lille, France; paul.picavet@gmail.com.

${ }^{2,4}$ Ghent University - Faculty of Arts and Philosophy, Department of Archaeology, Historical Archaeology Research Group (HARG), Sint-Pietersnieuwstraat35-UFO,B-9000 Ghent,Belgium; sibrecht.reniere@ugent.be,w.declercq@ugent.be.

${ }^{3}$ Ghent University - Faculty of Sciences, Department of Geology, Krijgslaan 281, S8, B-9000 Ghent, Belgium; veerle.cnudde@ugent.be. ${ }^{5}$ Geological Survey of Belgium, OD Earth and History of Life, Royal Belgian Institute of Natural Sciences; Gallo-Roman Museum, Tongeren \& Department of Archeology, Ghent University, Belgium; roland.dreesen@telenet.be.

${ }^{6}$ GEGENAA (EA3795), Université de Reims Champagne-Ardenne, 2 Esplanade Roland Garros, F-51100 Reims, France; gilles. fronteau@univ-reims.fr.

${ }^{7}$ Geological Survey of Belgium, OD Earth and History of Life, Royal Belgian Institute of Natural Sciences, 13, Rue Jenner, B-1000 Brussels, Belgium; eric.goemaere@naturalsciences.be.

${ }^{8}$ Gallo-Roman Museum, Kielenstraat 15, B - 3700 Tongeren, Belgium; else.hartoch@limburg.be.

*corresponding authors: paul.picavet@gmail.com - +33(0)6246740 76, gilles.fronteau@univ-reims.fr - +33 (0)326773687.
\end{abstract}

ABSTRACT. For some years, a French-Belgian team of archaeologists and geologists is investigating the provenance of ancient quernstones and millstones. Their study revealed the frequent occurrence of particular coarse sandstones derived from Lower Devonian strata in the Ardenne region, known as either the "Arkose of Haybes" by geologists or the "Arkose of Macquenoise" by archaeologists.

Material for Late Iron Age and Roman quern-stones and millstones was quarried from open pits located west of the border between France and Belgium, between the Belgian village of Macquenoise (Commune of Momignies, Province of Hainaut) and the French town of Hirson (Aisne Department, Hauts-de-France region). This paper describes the raw materials, presents the different types of grindstones produced through historical times and provides a detailed diffusion map of the millstones.

KEYWORDS: arkose, Lochkovian, milling stone, Gallo-Roman quarry, distribution area, geoheritage.

RÉSUMÉ. Le Grès de Macquenoise, une ressource naturelle du Lochkovien (Dévonien) adaptée à la réalisation de meules à grains : carrières, propriétés du matériau, fabrication et diffusion des meules (Belgique - France). Depuis quelques années, une équipe franco-belge d'archéologues et de géologues travaille sur la caractérisation des roches meulières. Notre étude a révélé l'utilisation fréquente de grès grossiers dévoniens originaires du Massif des Ardennes pour la fabrication de meules rotatives antiques. Ces grès sont connus sous l'appellation d"“Arkose d'Haybes" par les géologues et d'“Arkose de Macquenoise" par les archéologues. Depuis la Protohistoire et jusqu'à la fin de la période romaine, des meules ont été extraites de carrières à ciel ouvert situées à l'ouest de la frontière franco-belge, entre le village belge de Macquenoise (Momignies, Province de Hainaut) et la ville française d'Hirson (Département de l'Aisne, Région des Hauts-de-France). Le but de cet article est de présenter les grès lochkoviens exploités à cet endroit, ainsi que les meules à grains produites à l'époque gallo-romaine dans les différentes carrières de ce district meulier. Ces productions étant désormais bien identifiées et reconnues en de nombreux sites archéologiques de France et de Belgique, il est possible de proposer une carte précise de la diffusion de ces meules en "Grès de Macquenoise".

MOTS-CLÉS: arkose, Lochkovien, meule, carrière gallo-romaine, aire de diffusion, patrimoine géologique.

\section{Introduction}

Before the industrial era, milling stones ${ }^{1}$ were omnipresent in the daily life of people for food preparation and specific quarries were operational as early as Neolithic times and throughout History in order to produce these increasingly advanced tools (Jaccottey \& Milleville, 2010). During Neolithic and Protohistory, they consisted of a slab or saddle quern, on which a smaller rubbing stone was implemented (Hamon, 2008). From the Late Iron Age onwards and in the Roman period, the hand mill was operated by rotary movement (Jaccottey et al., 2013; Wefers, 2011): it was used by each household and consisted of two overlapping circular stones: the catillus (running upper quern) and the meta (stationary lower quern). At the same time and from the $1^{\text {st }}$ century AD onwards, the development of hydraulic and animal geared mills in northern Gaul clearly demonstrates the technical progress that characterizes Europe and the Mediterranean Basin during Antiquity (Garcia \& Meeks, 1997).

With the development of preventive archaeology in Western Europe during the last decades, archaeological excavations have exponentially multiplied, providing an increasingly documented dataset of stone tools (grindstones, whetstones, axes, millstones, mortars...). The latter objects, and particularly the grain millstones, have the great advantage of being most resistant to weathering, hence they have high preservation potential (Delgado-Raack et al., 2009; Picavet et al., 2011; Gomart et al. 2015). Numerous fragments of small querns and larger millstones have been found on archaeological sites, providing new information on the history of domestic, craft and trade practices that were part of socioeconomic systems of the Ancient World. One way to reconstruct the latter systems is to analyse trade routes via the distribution of stone products (Santi et al., 2014; Clarkson \& Bellas, 2014; Berrocal-Rangel et al., 2016; Turmel et al. 2016). Our research project involves a team of geologists and archaeologists (e.g. Williams-Thorpe \& Thorpe, 1989; Gluhak \& Hofmeister, 2009; Cnudde et al., 2013; De Kock et al., 2015; Reniere et al., 2016). Its first objective is to characterize the raw materials of the querns and millstones, in order to differentiate between groups of similar lithology; additionally, geological and geographical provenances need to be traced by comparison with local and regional geomaterials taken from collections and sampled in the

Milling stone: grinding stone in general (FR: meule). Quern: hand driven milling stone, comprising saddle querns from Upper Paleolithic to Late Iron Age in Western Europe, and hand rotary querns from the Late Iron Age onwards. Millstone: large milling stone for animal, hydraulic or wind driven mill. 


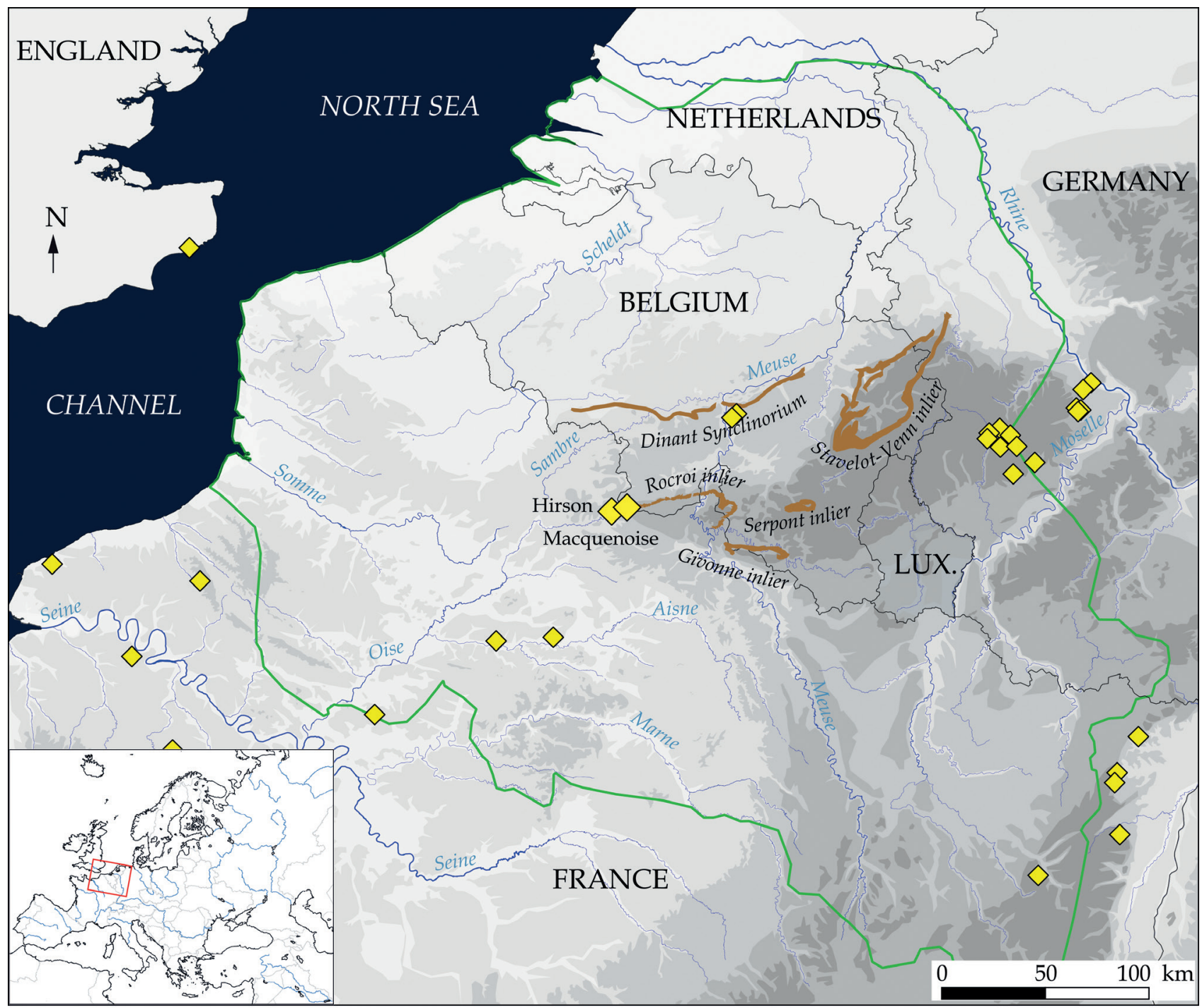

$\diamond$ Identified and supposed Roman quern quarries

Lochkovian units

Altitude :
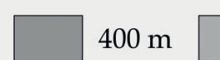

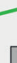

Figure 1. Location map of the study area, showing the Lochkovian lithostratigraphic units that have been used (after Corteel et al., 2004) and the connection with the Roman territories of Gallia Belgica and Germania Inferior. (Map and CAD: P. Picavet)

field; finally, we want to understand in which context the querns and millstones were distributed and operated.

In this way the ancient commercial roads and the economic organization of societies can be reconstructed, more especially by recording and mapping the distribution of the objects on archaeological sites and by identifying their original quarry sites.

During Antiquity, different raw materials have been selected for the manufacturing of querns and millstones, following particular criteria (Delgado-Raack et al., 2009; Boyer \& Fronteau, 2011; Hartoch et al., 2015): accessibility of the useful beds, workability, efficiency and durability (resistance) of the rock. In addition to the better-known volcanic rocks from the Eifel region used for the production of mills (Gluhak \& Hofmeister, 2009, 2011), our study revealed the frequent occurrence of different types of sedimentary rocks: Ypresian sandstones and puddingstones from the north-western Paris Basin (Picavet et al., 2011), Lutetian limestones from the northern Paris Basin (Robert \& Landréat, 2005), Thanetian quartzarenites from the Flemish Basin (Grès de Grandglise-Blaton: Reniere et al., 2016). The present paper focuses on the characterization and provenance of a particular group of conglomerates and coarse sandstones observed throughout the Roman provinces of Gallia Belgica and Germania inferior, an area that covers today the neighbouring regions of northern France, Belgium, Grand Duchy of Luxembourg, southern Netherlands and western Germany (Fig. 1).

\section{Methods}

The determination of the raw geomaterials is based on classic petrographic investigating techniques. The identification of the various lithologies is made through macro- and mesoscopic observations. For further detail, a comparative thin section analysis is applied in some cases. This has been done on rock specimens taken from both geological samples and archaeological objects. Furthermore, powder X-ray diffraction (PANanalytical Empyrean, $\mathrm{Cu}$ anthicathod, Ni filter, $30 \mathrm{~mA}$ and $40 \mathrm{kV}, 4$ to $70^{\circ} 2 \Theta$ ) was used to characterize the mineralogical content of the intergranular matrix of each material.

Finally, the stratigraphic assignment and the geological and geographical provenances can be pinpointed, based on a comparison with geological maps and on previous studies on these geomaterials (Bultynck \& Dejonghe, 2001; Corteel et al., 2004; Fieremans \& De Paepe, 1982). Within the context of this paper, we want to stress that the setup of ad hoc databases (e.g. Groupe Meule in France), the development of reference collections of raw materials and thin sections and the cross-border exchange of data and rock specimens, are essential to fill the numerous gaps in our knowledge (Dreesen et al., 2014). Once the rock types have been characterized, a thorough literature review and several field surveys are necessary to identify potential extraction traces. 
This last stage of investigation has been realized in February 2017 and provided some very relevant data on the petrographic, chronological and technical characterization of the Hirson/ Macquenoise millstone quarries.

\section{The Macquenoise "arkose"}

\subsection{Geographical and geological setting}

The Lower Devonian stratigraphic units of the Ardenne Allochton have been extensively studied across France, Belgium and Luxembourg (Dejonghe et al., 2017). The lowermost layers unconformably rest on the folded Lower Paleozoic basement around the Rocroi inlier, later affected by the North-Variscan fold-and-thrust belt. The Fépin Formation (FEP) is the earliest Devonian (Lochkovian, formerly named "Gedinnian") litho-stratigraphic unit: it is a conglomeratic formation composed of mixed fluvial and tidal marine deposits, that have been interpreted as alluvial fans (Meilliez, 1984; Meilliez \& Blieck, 1994; Meilliez, 2006). This formation is interpreted as a positive mega-sequence, corresponding to the Lower Devonian transgression on the Ardennes (Bultynck \& Dejonghe, 2001). In the type area, the old quarries of Fépin are not well preserved and the stratotype site of the Fépin Formation has been moved to the Lahonry quarry near Couvin (Fig. 2) (Meilliez \& Blieck, 1994). The Fépin Formation has been subdivided into two units: the Poudingue de Fépin or Fépin Conglomerate at the bottom and the Arkose d'Haybes at the top. The latter consists of greenishgrey sandstones interbedded with conglomerates and shales (Gosselet 1883a; Renard 1884). The lithological succession was further detailed by Gosselet (1888) subsequent to the works of Dumont (1848). Gosselet (1888) described various kinds of rocks and referred to the Macquenoise rock type in the Gedinnian as "Poudingue simple pisaire".

The Poudingue de Fépin and the Arkose d'Haybes units are frequently associated, e.g. in the Lahonry quarry (Maillieux, 1927; Meilliez, 1984; Van Ranst, 1977). They were grouped together by Asselberghs (1946). In the current lithostratigraphic subdivision, the Fépin Formation (FEP) groups all the coarse siliciclastic deposits located between the Lower Devonian unconformity and the Mondrepuis Formation (Bultynck \& Dejonghe, 2001; Meilliez \& Blieck, 1994; Meilliez, 2006). Consequently, the former name "Arkose d'Haybes" is no longer used. However, this ancient designation is still in use for local studies.
In addition to the Fépin/Haybes type area (Fig. 2A) and the Lahonry quarry lectostratotype (Fig. 2B), another important area displaying old quarries in the same formation is located between Hirson (Aisne, France) and Macquenoise (Hainaut, Belgium) (Fig. 2C). As described further (see 4.1.), the distinctive feature of this western outcrop area for the same formation is due to a series of ancient millstone quarries already interpreted as such since the $19^{\text {th }}$ century.

\subsection{Macroscopic and petrographic characteristics of the Macquenoise sandstone}

The Lochkovian sandstones near Haybes and Fépin show partially recrystallized, grey to greenish sandstones with winered clay rich patches or more shaly intercalations (Fig. 3A). The colours become brighter due to natural weathering. They represent arenites, ranging from medium-grained sandstones to conglomerates. Pebbles of green, black and grey quartzites, lydites, phyllites and white quartz are common, the size of which can reach several centimetres. Numerous millimetric to centrimetric fragments of black green tourmaline crystals occur in the matrix (initially described by Dumont, 1848 as hornblende crystals). This mineral is easy to recognize due to its strong colorimetric contrast with the pale background colour of the rock. However, tourmalinite pebbles seem to be absent. The intergranular matrix is composed of a whitish to greenish mixture of muscovite flakes and iron-rich chlorite flakes, the latter in low amounts.

The shiny, powdery and whitish colour of the matrix has often been erroneously interpreted as kaolinite resulting from the weathering of feldspars. As observed near Couvin, in the Lahonry quarry, by Van Ranst (1977), neither detrital feldspar grains nor their kaolinite weathering product are present in the rocks showing this so-called "kaolinitic" aspect. This observation is a strong argument for rejecting the old denomination of "arkoses" for these particular coarse sandstones in petrographic studies. Note also that Lower Devonian "arkoses", found around the Stavelot-Venn inlier, are also totally devoid of feldspars or kaolinite, whereas "true" arkoses and arkosic sandstones are well-known elsewhere in Belgium (Michot, 1963) (Annex 1). Paradoxically, Upper Famennian arkoses and arkosic sandstones of the Evieux Formation are simply called sandstones, maybe due to the absence of the characteristic small white weathering patches on the rocks (Thorez \& Dreesen, 1986).

The Macquenoise sandstone is the lateral equivalent of the so-called "Arkose d'Haybes", but with some particular features.

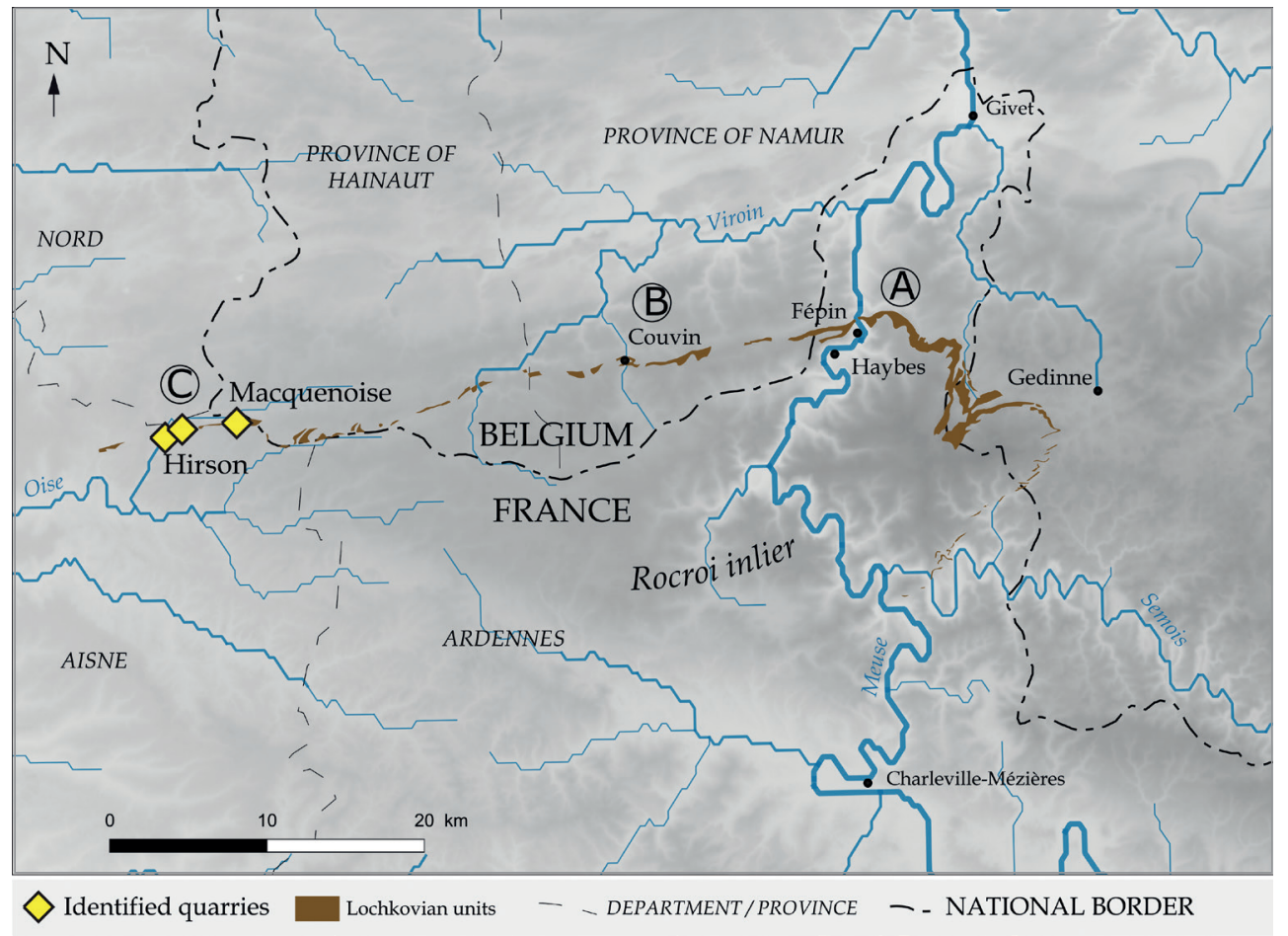

Figure 2. Map showing all the reference localities of Haybes/ Fépin (A), Lahonry (Couvin) (B), Hirson/Macquenoise (C) and the known extraction sites for Roman querns and millstones in the Lochkovian outcrops. (Map and CAD: P. Picavet) 


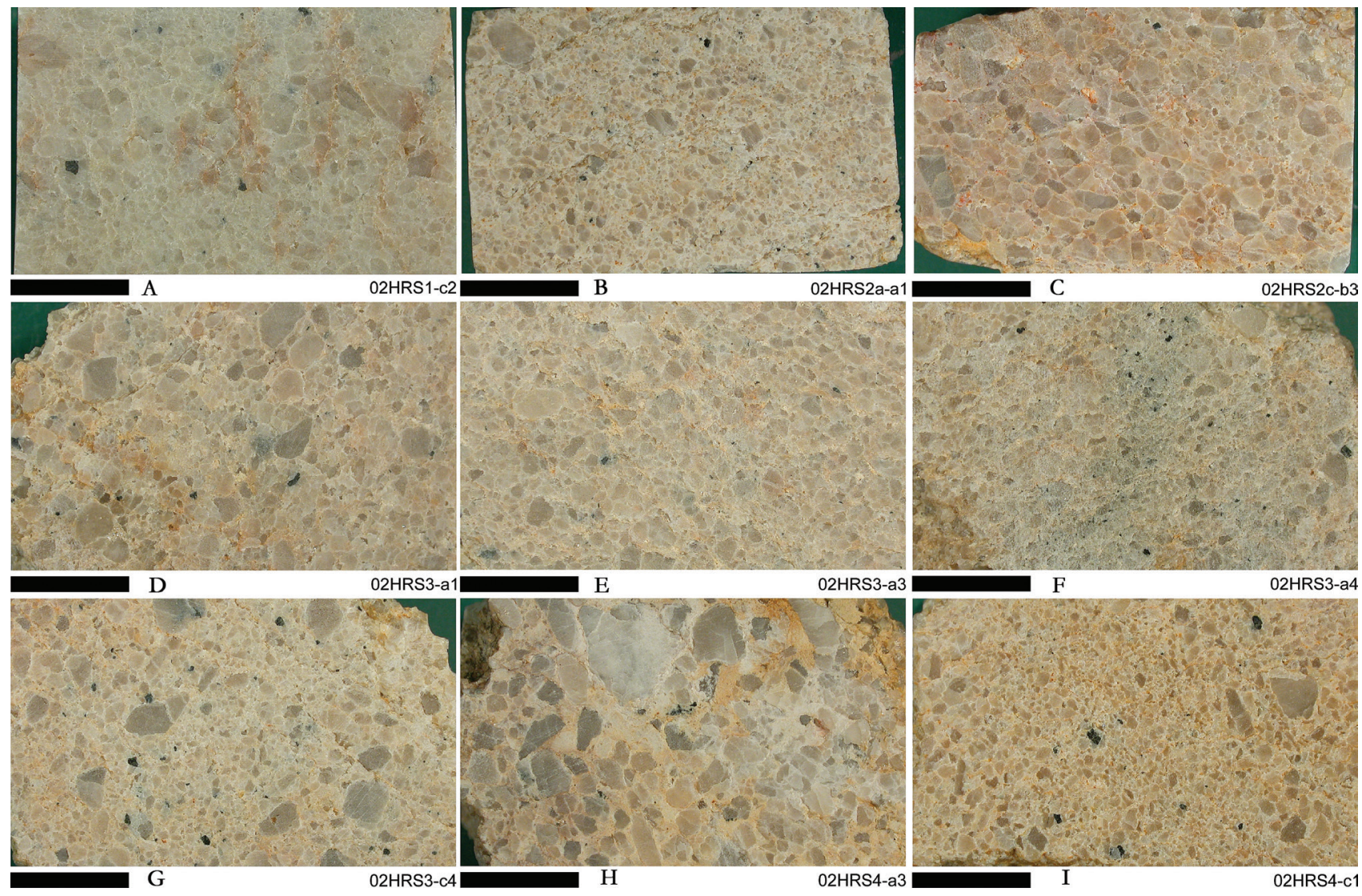

Figure 3. Polished slabs of various facies of Lochkovian sandstones from Hirson and Macquenoise. Note the few but omnipresent tourmaline crystals (black dots). Length of the black line: $1 \mathrm{~cm}$. (Photographs G. Fronteau)

Gosselet (1888) published a lithostratigraphic column of a currently badly preserved quarry located between Milourd and the site of Pas-Bayard (North of Hirson, see Fig. 6), in which he mentioned the abundance of millstones (Annex 2).

In this reference section, the pristine "arkosic" rocks were subdivided into eight different layers, from $0.30 \mathrm{~m}$ to $6.00 \mathrm{~m}$ thick, with two layers of intercalated shales. The "arkose" layer that we now call "Macquenoise sandstone" was indicated with a thickness of 4 metres in the second (upper) part of the formation.

This particular sandstone type, that was quarried for the production of millstones, is more homogenous than the different other beds observed within the Haybes/Fépin area (Fig. 4). It is a compact grey coarse sandstone (well-cemented or affected by higher compressive stress) or conglomerate, containing tiny amounts of dark green to black tourmaline crystals.

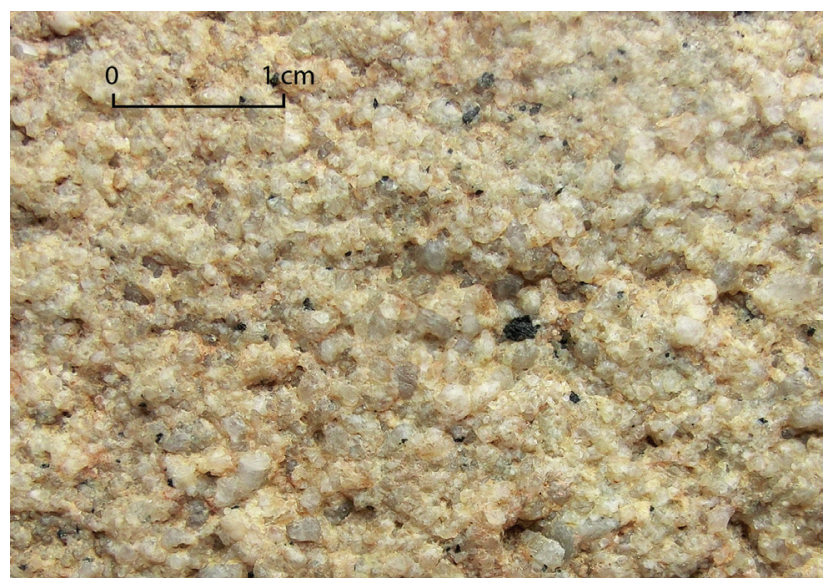

Figure 4. Macroscopic view of the surface of a Roman quern found in Dourges (Pas-de-Calais, France). Black dots are tourmaline crystals. (Photograph P. Picavet)
Macroscopically, the samples taken from the old and now totally infilled quarries between the Pas-Bayard quarry (Hirson, Aisne, France) and Macquenoise (Belgium), show a variability that matches well the description of the quarry made by Gosselet (1888) and the facies distinctions made by Dumont (1848): indeed, some beds are clearly green and compact, whereas other beds are more weathered with pinkish colours. However, other beds represent grey to white, heterometric sandstones and conglomerates enclosing small cobbles and coarse quartz grains or shale fragments. Moreover, some of them correspond rather to more homogeneous medium- to coarse-grained arenites (Fig. 5). In this latter "homogeneous" facies, quartz grains are closely packed and the phyllitic cement (or recrystallized matrix) is less well-developed, enclosing small amounts of tourmaline crystals (less than 1\%): the presence of tourmaline seems to be a good marker for identifying this particular rock type. The largest tourmaline grains (up to $1 \mathrm{~cm}$ ) display a colour zoning in planar polarized light (PPL): colourless at the margins with bottle-green or indigo hues in the core. The tourmaline crystals show broken triangular prisms with strong vertical striation and curved faces (rounded triangles in cross section). Tourmaline is a common accessory mineral in Lower Devonian detrital sediments. It is a chemically and mechanically resistant that occurs together with other heavy minerals such as zircon, rutile, apatite (automorphic crystals to well-rounded grains) and $\mathrm{Fe}$-Ti minerals (ilmenites, leucoxenes, titanomagnetite...). The genesis of tourmaline (schorl-dravite series), in tourmalinite pebbles found in Belgian Lower Devonian conglomerates, was studied earlier by Fieremans \& De Paepe (1982).

Various kinds of sandstones can be identified with petrographic methods (Fig. 4): heterometric sandstones, with few very coarse grains among medium to coarse quartz grains, with some grains floating in a recrystallized interstitial material (composed of micas and sericite microflakes) (Fig. 5A, B \& D); very coarse sandstones to conglomerates displaying some stacked components (Fig. 5C); and finally, well-sorted, medium- to coarse-grained sandstones (Fig. 5E). The microfacies of this large, heterogeneous group of 

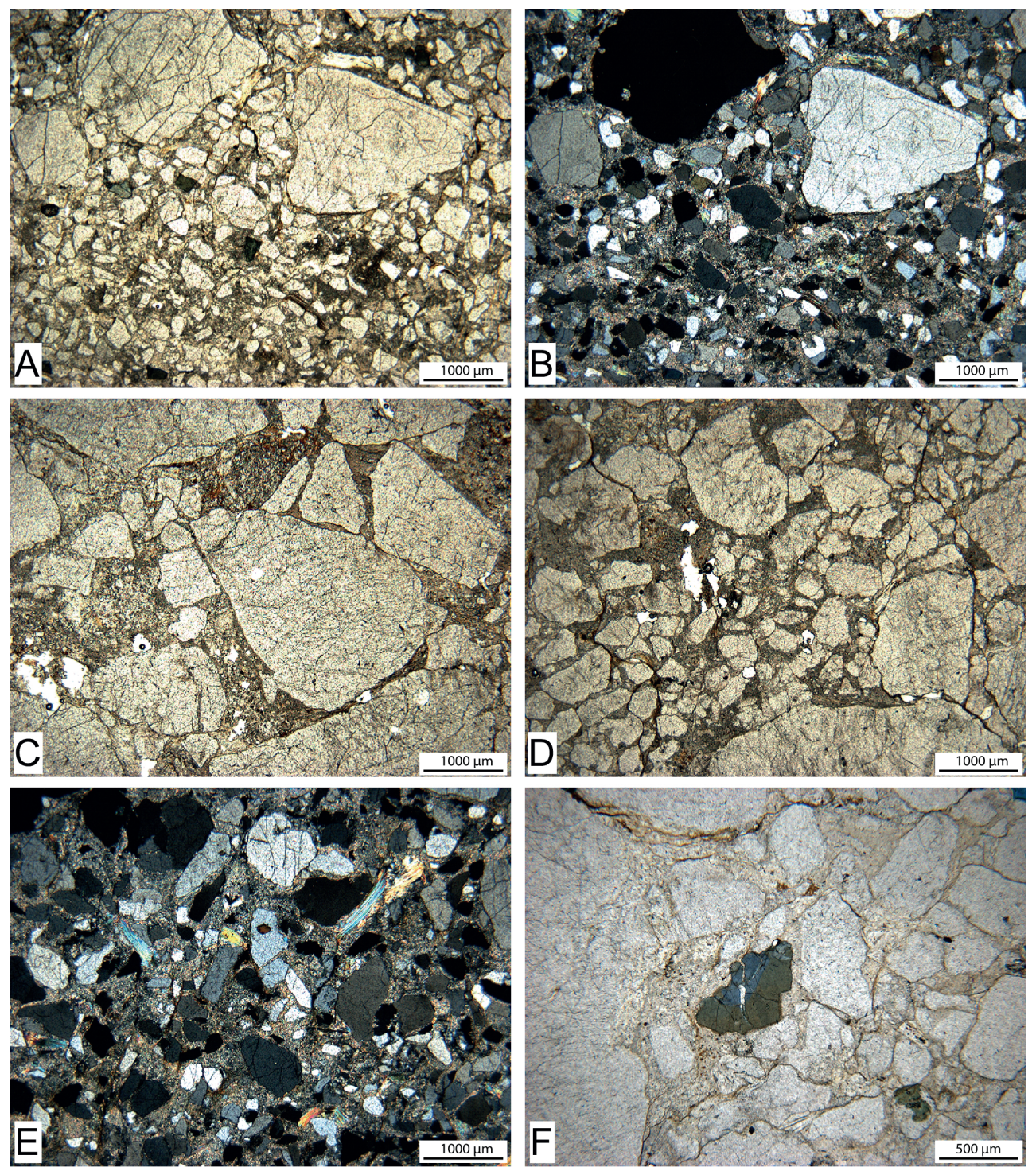

Figure 5. Micrographs of various sandstone facies from Macquenoise. A, C, D, F in plane polarized light, B \& E between crossed polars. (Photographs G. Fronteau)

lithic wackes, quartzwackes, sublitharenites and conglomerates, shows abundant quartz grains (mainly monocrystalline, with cracks and undulose extinction), a few muscovite flakes (Fig. 5E) and green-brown to blue tourmaline crystals (Fig. 5F).

This petrographic description is very analogous with that of Van Ranst (1977) who analysed six samples from the Lahonry quarry near Couvin. He point counted 72.2 to $78.7 \%$ of quartz grains, 18.1 to $22.3 \%$ of matrix, 1.4 to $7.1 \%$ of mica (detrital mica + recrystallized matrix in the form of microflakes), 0 to $0.8 \%$ of tourmaline and only 0 to $0.5 \%$ of microcline and 0 to $0.1 \%$ of plagioclase.

Disoriented powder X-ray diffraction analyses were performed on seven samples of coarse sandstones, taken from the Macquenoise quarry district. The whitish sandy matrix was separated and grinded (below $56 \mu \mathrm{m}$ ). The analytical results show the presence of quartz, micas (probably a mixture of illite-2M1 and phengite) in all samples, while iron-rich chlorite occurs only in one sample. Feldspars and kaolinite are totally absent or below the detection limit.

\section{The Lochkovian sandstone quern quarries}

\subsection{The old quarries of Macquenoise: potential geoheritage sites}

The ancient millstone quarrying district, located in the neighbourhood of Macquenoise, is known since the $19^{\text {th }}$ century. It is located on the northern border of the Rocroi inlier, near the source of the Oise river, straddling the French departments of Aisne and Nord, and the Belgian province of Hainaut (Fig. 6). Three different sites display a series of deep pits ( 5 to 10 metres deep) surrounded by high embankments of extraction debris. However, all these features are now covered by humus, whereas unfinished querns and millstones still witness of former quarrying activities.

Before the descriptions of Gosselet (1888), the siliciclastic formations of the Macquenoise area were poorly understood. Guettard (1780) briefly mentioned the Macquenoise rock type (it seems that he did not visit the quarry himself) and defined it as a "singular stone, kind of granite?", "perhaps only a variety of quartz or the slated beds", known at that time by the forge masters of Chimay as they used it for the refining area of their furnace.

Gosselet (1888) already noted lateral variations of the rock, not only from one outcrop to another, but also within a same outcrop. Furthermore, he pointed to the fact that only one particular bed seemed to have been preferentially used (see Annexe 3). In agreement with this remark, we observe a great homogeneity of the facies used for quern making, as early as from the end of the Iron Age. As shown before (see 3.2.), this dominant sandstone facies (a white to beige coarse arenaceaous rock with homogeneous distribution of millimetric tourmaline grains) is systematically identified when petrographic analysis was carried out. This leads us to the identification of a unique quarry district (i.e. one area with several closely spaced quarries in the same outcrop zone of a particular rock type) that has been intensively exploited for quern manufacturing during Antiquity, and whose products had a widespread distribution and must have possessed a 


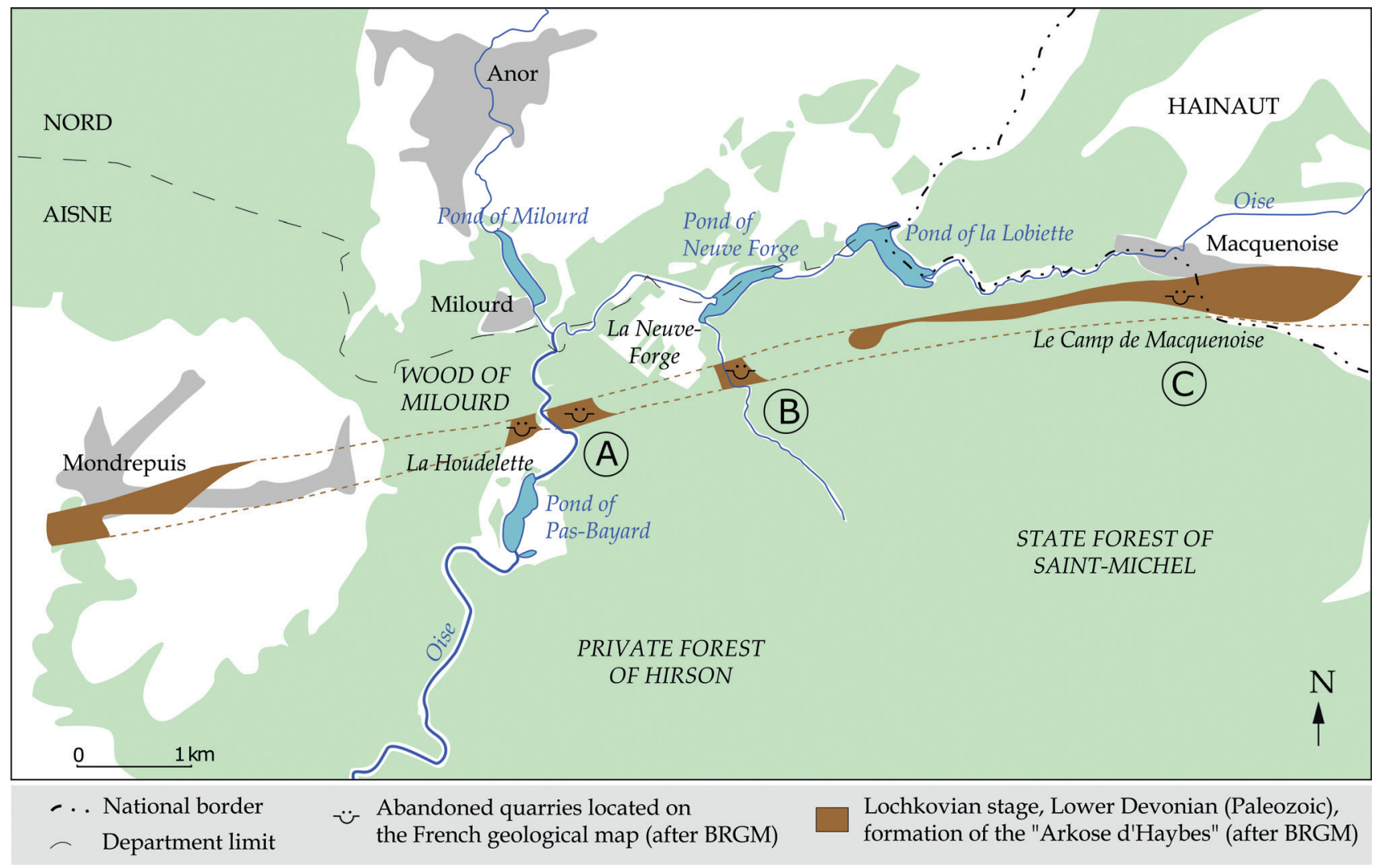

Figure 6. Map of the Hirson (Aisne, France) and Macquenoise (Hainaut, Belgium) quarry district. A: Site of the "Pas-Bayard". B: Site of "Neuve Forge". C: The "Camp de Macquenoise". (CAD: P. Picavet, after IGN and BRGM)

considerable commercial importance (Picavet et al., 2011).

Nowadays, these sites are badly known by Heritage authorities, although they represent important human industrial archaeological heritage, and they are threatened by the lumbering activity that increasingly uses powerful machines.

\subsection{Other millstone quarries in Lochkovian sandstones}

Other sites quarrying Lochkovian sandstones and conglomerates are known further to the east within the Ardenne, more especially around the Stavelot-Venn inlier, but they only show a few remains of protohistoric saddle quern making (Jottrand \& Cumont, 1901; Lejeune, 1979; d'Otreppe, 1994) and of medieval millstone manufacturing (Grailet, 2003). Although numerous small quarries and unfinished millstones are scattered along the outcrop between Baraque de Fraiture, Vielsalm (Province of Luxembourg, Belgium) and Recht/Sankt-Vith (Province of Liège, Belgium), there is still no evidence yet of Late Iron Age or Roman extraction.

In the same way, we have no proof for millstone quarrying activities during Antiquity in the local Lochkovian sandstones in the areas of Haybes, Fépin, Hargnies (Ardennes, France), Willerzie or Couvin (Province of Namur, Belgium), although some very sparse medieval/modern rough millstones were observed around Hargnies (where an unfinished contemporary millstone is also named "Pas-Bayard rock").

Around the smaller Serpont inlier, more especially in the surroundings of Freux (Province of Luxembourg, Belgium), a Neolithic or protohistoric saddle quern quarry has recently been identified that extracted Lochkovian sandstone beds (Picavet, 2017). However, to date there is still no evidence for rotary quern manufacturing.

\subsection{Age of quarrying}

In the Macquenoise and Hirson quarry district, the lack of recent archaeological excavations does not allow to specify the exact age of quarrying. Nevertheless, the rotary querns and millstones that were derived from these quarries were found in reliably dated archaeological contexts and allow an estimation of the duration of the extraction activity, as from the Late Iron Age through the Late Antiquity (Picavet et al., 2017). The place has only been reoccupied during Middle Ages by a castle that has been interpreted for a long time as a possible Roman military camp. This explains its different mythical names such as "Camp de César", "Camp de Macquenoise" or "Camp des Sarrasins". This castle is known in the literature since the $12^{\text {th }}$ century and has later been dismantled to supply characteristic pale-coloured building stones for the construction of the village houses in Macquenoise. A few unfinished querns can still be found among the ruins of the castle, demonstrating that Iron Age and Roman extraction wastes have been directly used for its construction.

The first real archaeological description of the quern manufactory district goes back to the work of Édouard and Amédée Piette (Piette, 1847), who mentioned a fortified rampart defending the entry of the Oise Valley.

The Prince of Chimay launched in 1864 an excavation campaign in the "Camp de Macquenoise" with the objective to collect precious artifacts (Chambon, 1954; Deflorenne, 1973). He was first to identify the presence of unfinished querns and to lend an industrial origin to the area.

We must then wait until the end of the $19^{\text {th }}$ century to observe a methodical archaeological survey on the French side, by the members of the Société Archéologique de Vervins, who carried out large prospection campaigns throughout the forest (Rogine, 1876, 1880, 1881; Mennesson, 1877, 1880). These field observations of the existence of quarries were first compiled by Desmasures, who published a History of Saint-Michel (a small village to the east of Hirson) (Desmasures, 1883). A few years later, Jottrand (1886, 1895), who was more interested in his native Vielsalm district (Stavelot-Venn inlier), raised the Macquenoise issue on the Belgian side and elaborately described the Ancient quern making industry in Belgium. Later on, all available documentation on the Roman querns of Macquenoise, has been synthesized by Chambon (1954) and Deflorenne (1973). Thanks to the latter, it has been possible to locate the ancient quarries that provided Northern Gaul with querns and millstones. 


\subsection{The quarries}

In the Hirson and Macquenoise area, the bedrock crops out discontinuously and three main extraction sites are identified on the French geological map (BRGM) and listed as abandoned quarries (Fig. 6). In these locations, the landscape shows a succession of deep excavations surrounded by high piles of rock debris. Moreover, unfinished querns, broken querns and flakes from roughly shaped pieces, were observed amidst these remains at the end of the $19^{\text {th }}$ century (Rogine, 1880 \& 1881); unfortunately, only very few are still in place today.

The westernmost quarry is located to the north of "PasBayard" pond (Fig. 7). On the west bank of the Oise river, the first appearance of the bedrock is reached in a narrow and deep trench, that forms the working face of a quarry exploited during the Modern period (comprised between the Late Middle Age and the Late $18^{\text {th }}$ century) for the extraction of shales and sandstones. This quarry, with its steep $20 \mathrm{~m}$ high walls, is already mentioned by Mennesson (1877) and Rogine (1880) as the "Houdelette" quarry, referring to the name of an ancient landlord.

According to the above authors, this abandoned quarry is prior to the $19^{\text {th }}$ century, because it faded from local memory at the time of their visit. Moreover, the neighbouring village of Anor is not built with this rock but rather with the thinner-bedded Lower Devonian "Anor sandstone". According to Rogine (1880), the "Houdelette" quarry can be linked with the erection of local post-medieval forge furnaces. It is now used as a climbing wall.

Opposite to this well-exposed abandoned quarry, on the east bank of the Oise river, a succession of excavations surrounded by high dumps of stone debris are covered by vegetation and are less well-accessible. Unfinished rotary querns and larger millstones have been recovered, providing good evidence for Roman extraction activities. The western "Houdelette" quarry might have been mined in the same way during Antiquity, but good evidences of this activity most probably disappeared as a result of younger extraction activities.

Following the bedrock to the east, we find the same pattern of excavations and spoil heaps, south of the locality named "Neuve Forge" ("Neuforge" in the $19^{\text {th }}$ century texts, Anor) (Fig. 8A). The quarry remnants are spread on either side of the valley, at the bottom of which the forest road of "Gratte Pierre" crosses a small watercourse running to the Oise river. Here, unfinished saddle querns have been found without evidence of rotary quern production. The rock extraction on this site is thus prior to the Late Iron Age.
The easternmost ancient quarry, better known as the "Camp de Macquenoise", is located directly to the west of the French-Belgian border, at the exit of the village of Macquenoise (Hainaut, Belgium) but still in France (communes of Saint-Michel and Hirson: Fig. 8B). Here, a large quantity of round-shaped excavations and spoil heaps, extending over almost $1 \mathrm{~km}$ following the strike of the beds, crosses the road leading to Hirson (Aisne, France), and fades away at the administrative boundary between the townships of Saint-Michel and Hirson. Small, unfinished querns of $40-50 \mathrm{~cm}$ diameter have been found in this area during the $19^{\text {th }}$ century, witnessing of quern manufacturing activity during Antiquity. Unfinished saddle querns prove that there was an earlier exploitation but traces of the latter became obliterated by the Roman industry and the construction of the medieval fort. Moreover, monolithic coffer tombs for GalloRoman funerary urns made from the same material, were found in the forest of "la Spoitinelle" at Macquenoise in 1860 (Cattelain, 2015-2016). Finally, the same material was used for the construction of the baths of the Gallo-Roman village of Macquenoise (Brulet, 1982-1985).

\subsection{Operating mode}

Although an archaeological excavation would be necessary to confirm the quern production process and its chronology, our field survey already provides some preliminary insights. The large pits served to the extraction of raw blocks, and the $10 \mathrm{~m}$ high embankments are formed by an accumulation of quarrying and carving wastes. After being roughly cut, a cylindrical shape is given to the blocks by the peripheral removal of shaping debris and the formatting of two opposite flat faces (Fig. 9A). The surface is then regularized by finer work as noted on a few pieces in the quarries (Fig. 9B). Our surface survey failed to observe many artefacts and we could not find any rough querns with the eye and handle socket holes already drilled. This may reveal that this stage could only be realized in peripheral workshops, as well as the carving of the grooves on the grinding surface.

This modus operandi of raw block extraction and surface roughening, followed by a finishing in peripheral workshops, is common during Antiquity (in Avrilly, Eure, France: Guillier et al., 2005; in La Salle, Vosges, France: Farget \& Fronteau, 2011; in Collonges-en-Charollais, Saône-et-Loire, France: Jaccottey et al., 2011) but is not a general rule. In some cases, cylinders are directly extracted (e.g. in Châbles, Switzerland: Anderson et al., 2003; in Saint-Quentin-la-Poterie, Gard, France: Longepierre, 2012). This discrimination can be explained by differences in chronology, geography or more probably by the way the material crops out.

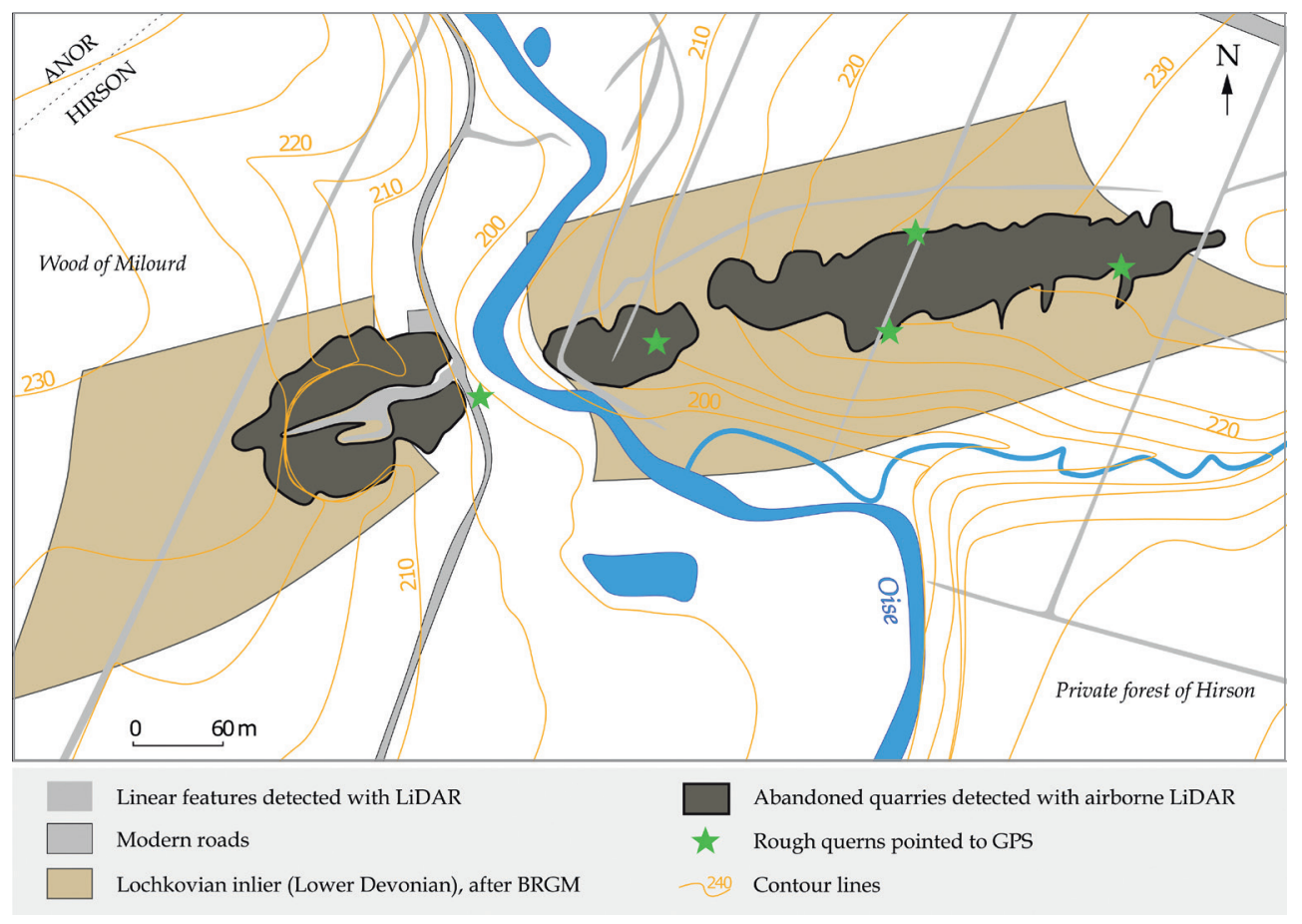

Figure 7. Detailed location map of the "Pas-Bayard" quarries in Hirson, France, drawn on the RGE ALTI ${ }^{\circledR}$ digital terrain model (IGN). (CAD: P. Picavet) 

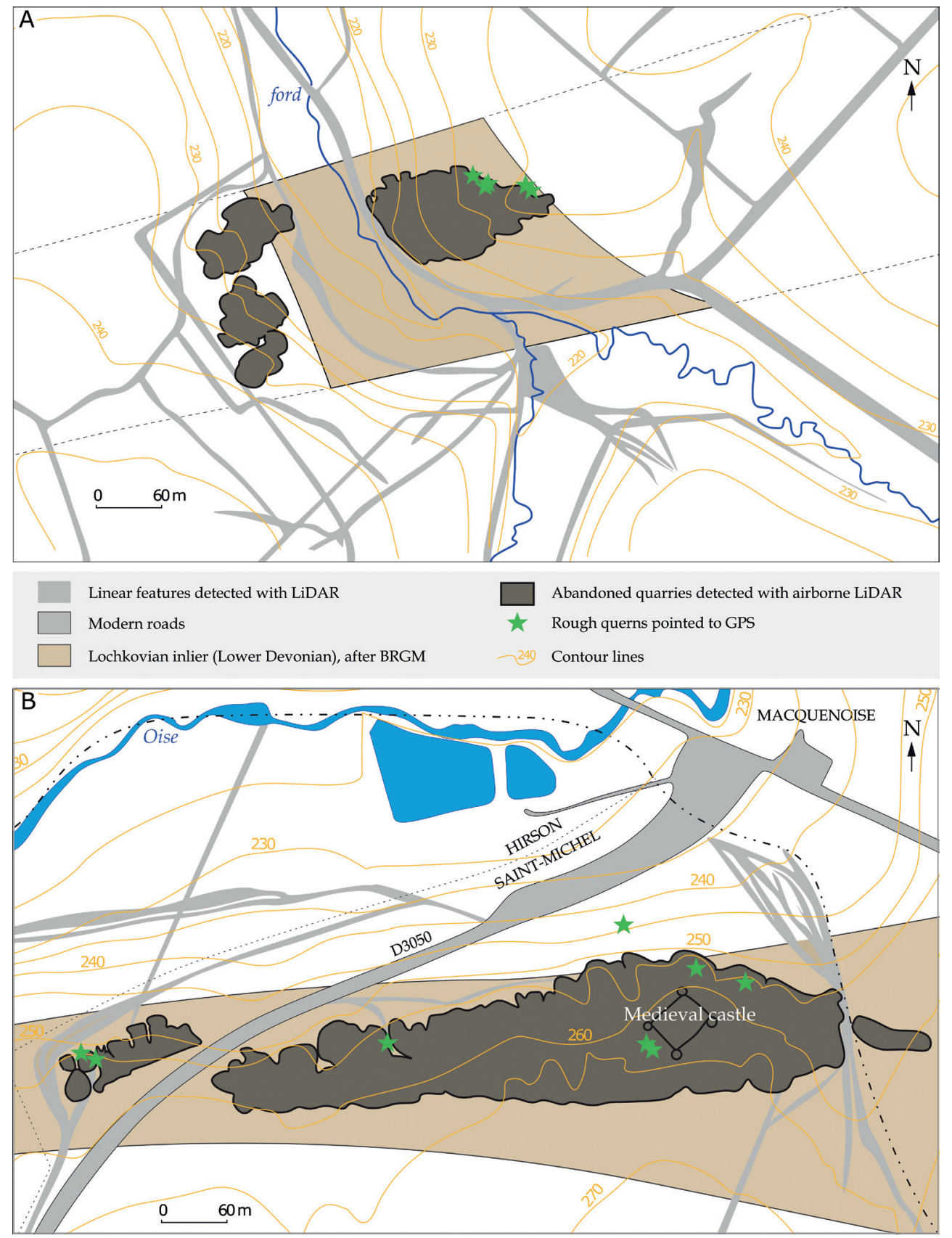

Figure 8. A: Detailed location map of the "Neuve Forge" quarry, Anor, France. B: Detailed location map of the "Camp de Macquenoise". Drawn on the RGE ALTI digital terrain model (IGN). (CAD: P. Picavet)
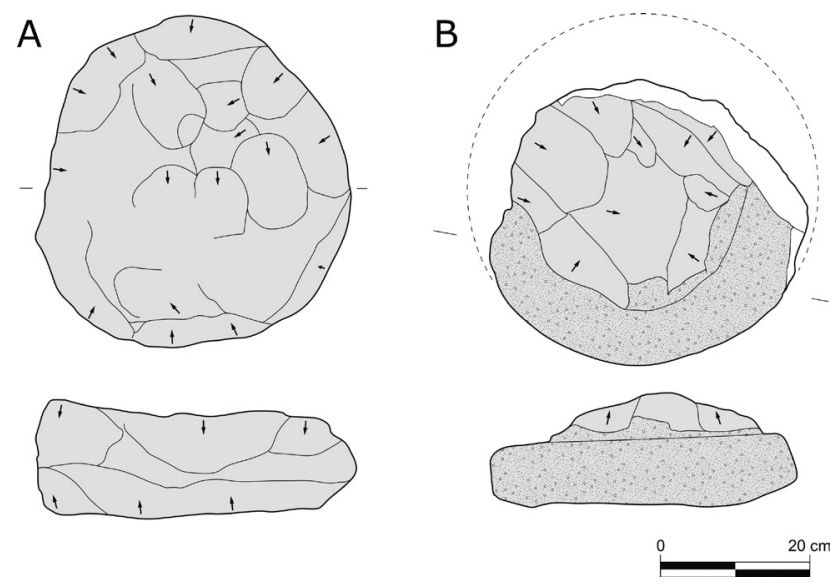

Figure 9. Examples of Roman rough rotary querns found at the "Camp de Macquenoise", Hirson (France). A: first stage: peripheral removal of shaping debris; B: second stage: fine regularization of surfaces by picketing. (Drawings scale 1/10, CAD P. Picavet)

\section{Production of the Macquenoise quarries}

Prior to the Late Iron Age and before the adoption of a rotary movement for mills, evidence exists for the production of saddle querns in the Hirson and Macquenoise area, at least in two of the three studied sectors. On archaeological sites, saddle querns made from Macquenoise-type (Lochkovian) sandstone are found since the Middle Neolithic through the Iron Age in Northern France, Belgium, The Netherlands and Luxembourg. For these periods, a variety of provenance areas is proposed, such as the Stavelot-Venn, Serpont and Rocroi inliers (Fig. 10).

For the Late Iron Age and despite the discovery of one rough rotary quern at the "Camp de Macquenoise", production activities are badly known. The latter consist of the manufacturing of small hemispherical hand mills in which a lateral handle socket is carved out, horizontally extended into the middle of the quern (Fig. 11A). Such querns are found in small quantities on a few Late Iron Age settlements, mainly in Acy-Romance (Ardennes, France: Buchsenschutz et al., 2017), located about $50 \mathrm{~km}$ from the above quarries to the south.

During Roman times, two main types of milling stones were produced: rotary hand querns for domestic food preparation (Fig. 11B) and larger millstones for animal and hydraulic geared 


\begin{tabular}{|c|c|c|c|c|c|}
\hline & & ROCROI INLIER & & SERPONT INLIER & STAVELOT-VENN INLIER \\
\hline & Hirson/Macqu & enoise & Fépin/Hargnies & & \\
\hline Modern times & $\begin{array}{l}\text { "Camp de } \\
\text { Macquenoise": } \\
\text { - Construction of } \\
\text { the village } \\
\text { - Antiquaries spoliation } \\
\text { - First excavations }\end{array}$ & $\begin{array}{l}\text { "Pas-Bayard": } \\
\text { forge furnaces? }\end{array}$ & & & \\
\hline Middle Ages & $\begin{array}{l}\text { "Camp de Macquenoise } \\
\text { Medieval fort, } \\
\text { 12th century onward }\end{array}$ & & $\begin{array}{l}\text { Hargnies } \\
\text { "Pas-Bayard rock": } \\
1 \text { large rough } \\
\text { millstone }\end{array}$ & & $\begin{array}{l}\text { Salmchâteau/ } \\
\text { Burtonville: } \\
\text { large rough millstones }\end{array}$ \\
\hline $\begin{array}{l}\text { Roman } \\
\text { Antiquity }\end{array}$ & $\begin{array}{l}\text { "Camp de } \\
\text { Macquenoise": } \\
\text { circular rough querns }\end{array}$ & $\begin{array}{l}\text { "Pas-Bayard": } \\
\text { circular rough } \\
\text { querns }\end{array}$ & & & \\
\hline $\begin{array}{l}\text { Late } \\
\text { Iron Age }\end{array}$ & $\begin{array}{l}\text { "Camp de } \\
\text { Macquenoise": } \\
1 \text { circular rough quern }\end{array}$ & & & & \\
\hline Protohistory & $\begin{array}{l}\text { "Camp de } \\
\text { Macquenoise": } \\
\text { rough saddle querns }\end{array}$ & $\begin{array}{l}\text { "Neuve Forge": } \\
\text { rough saddle } \\
\text { querns }\end{array}$ & Fépin? & $\begin{array}{l}\text { Freux } \\
\text { "Bois de la Hé": } \\
\text { rough saddle querns }\end{array}$ & $\begin{array}{l}\text { Salmchâteau/ } \\
\text { Burtonville/Recht: } \\
\text { rough saddle querns }\end{array}$ \\
\hline
\end{tabular}

Figure 10. Panorama of past activities on different Lochkovian outcrops (from Jottrand, 1895; Picavet, 2017; Picavet et al., 2017).

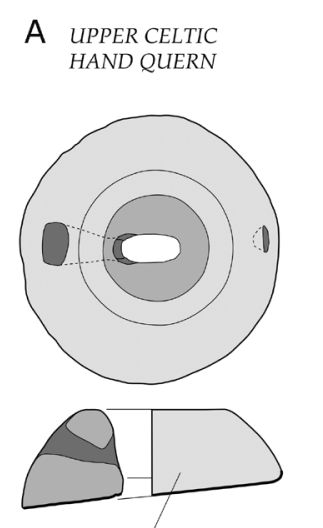

Front view
B

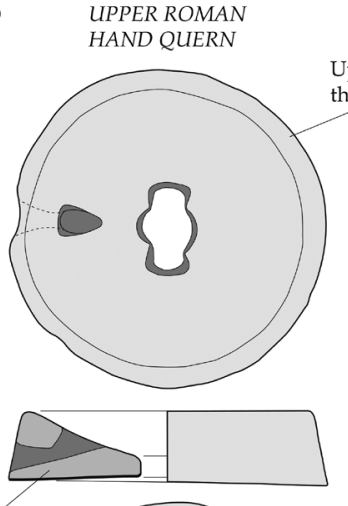

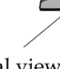

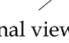

nal view
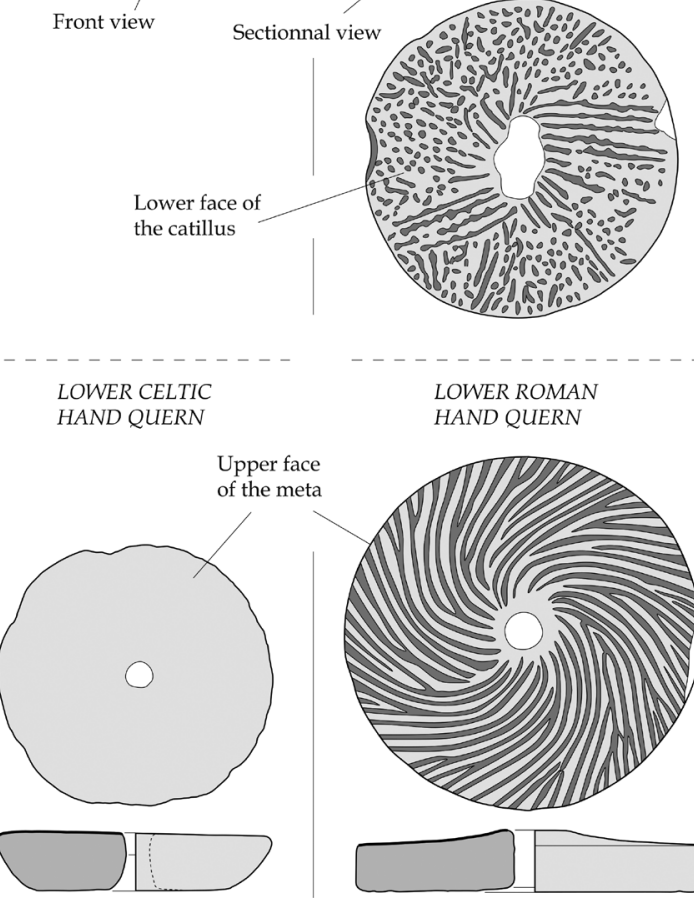

LOWER ROMAN HAND QUERN

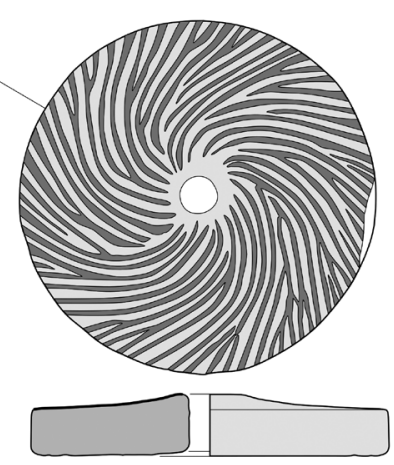

C UPPER ROMAN MILLSTONE
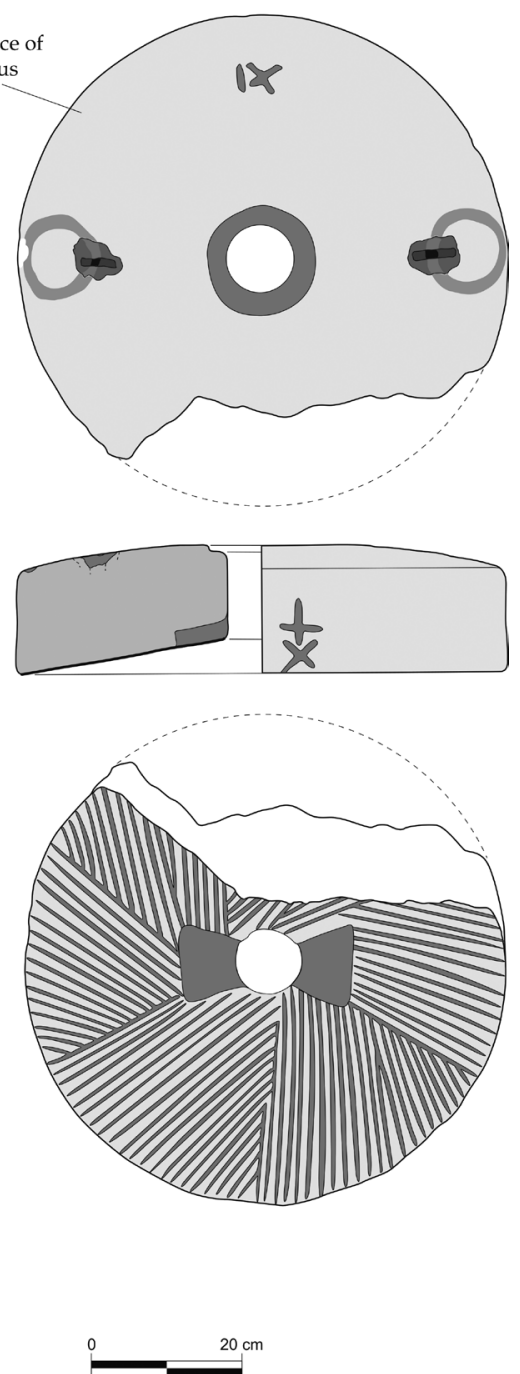

Figure 11. Different types of rotary querns and millstones produced in the quarries of Macquenoise. A: Late Iron Age hand querns. B: Roman hand querns. C: Roman hydraulic millstone. (Drawings scale 1/10, CAD: P. Picavet) 
A

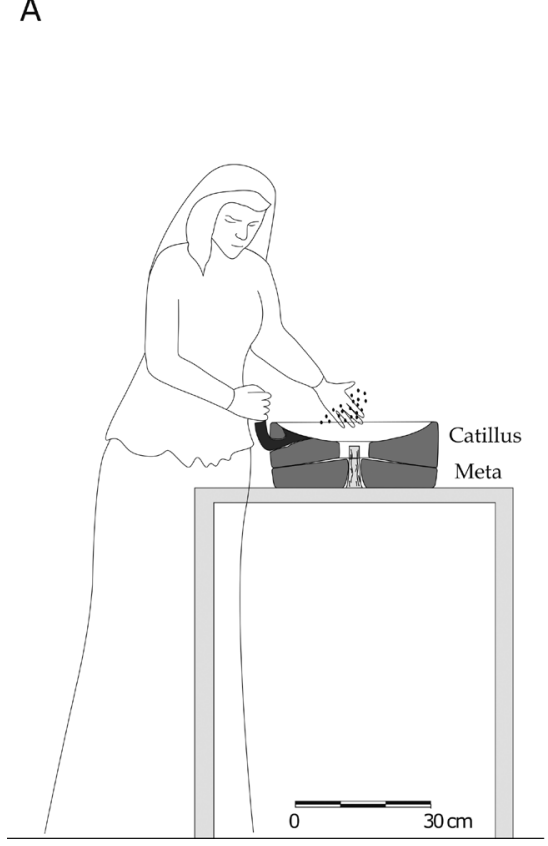

B

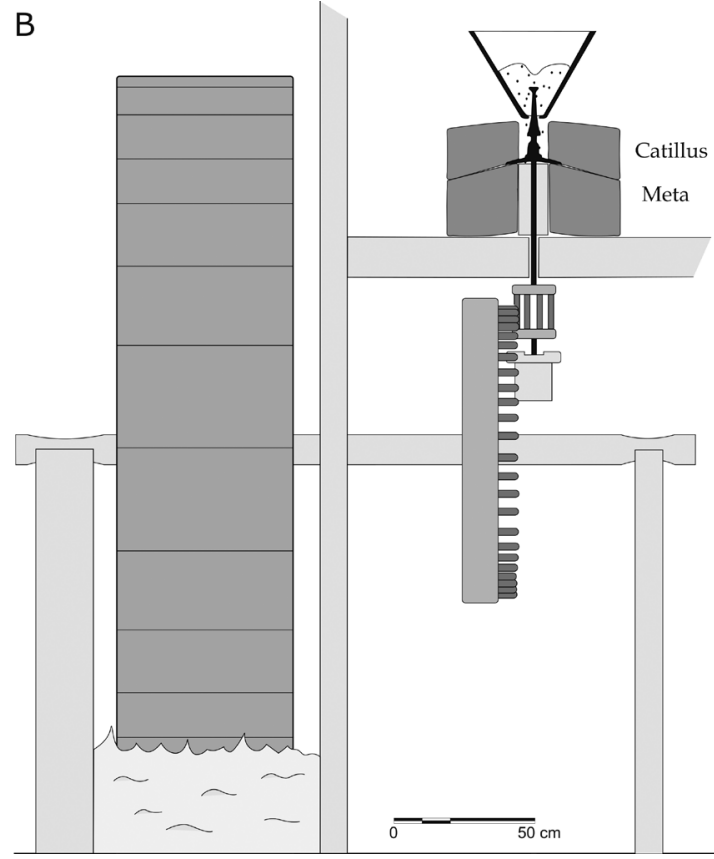

Figure 12. A: The hand mill in operation. B: Operating principle of the water mill. The millstones are shown in sectional view. (CAD: P. Picavet) mills (Fig. 11C). Both types are differentiated from each other by their dimensions and by the technical facilities adapted for each technique of drive. The morphological limit between hand and mechanical driving is theoretically established around $50 \mathrm{~cm}$ diameter, corresponding to the range of the human arm (Baatz, 1995).
Hand mills are present on all kinds of archaeological sites, in towns as well as in the countryside. These were essentially used for domestic food supply (Fig. 12A). Hydraulic and animal geared mills were used when a larger population had to be fed, for example in military camps (like in Arras, Pas-de-Calais, France: Picavet, 2014) or in rural villas (in Harnes, Pas-de-Calais,

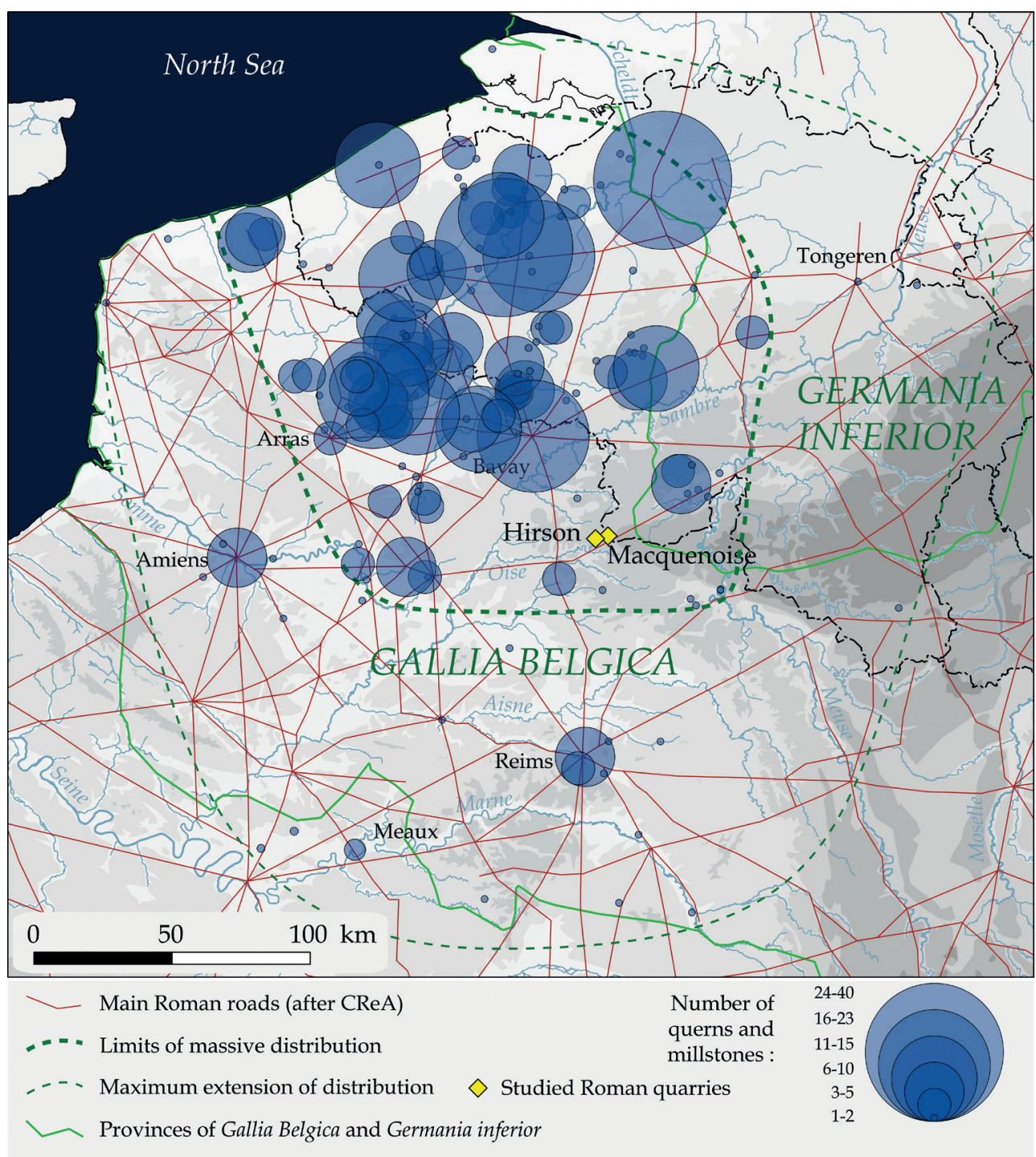

Figure 13. Distribution map of the Roman querns and millstones made of Macquenoise sandstone (Lochkovian), related to the Ancient communication network. (Map and CAD: P. Picavet) 
France: Picavet, 2014) (Fig. 12B). In the roman cities of Northern Gaul, e.g. Bavay (Nord, France) or Amiens (Somme, France), small querns and large millstones are both present, showing the conjunct practice in Antiquity of a domestic hand grinding activity and large-scale food preparation probably taking place in bakeries.

\section{Distribution of Macquenoise sandstone querns and millstones during Roman times}

The distribution area of the querns and millstones on archaeological sites is rather eccentric and is clearly heading northwards, in a region almost devoid of suitable raw material for quern manufacturing (Fig. 13). This area, without being concentric around the Macquenoise sandstone outcrops, is very coherent and reinforces (based on the petrographic and morphologic homogeneity of the querns) the idea of a unique production centre feeding the market in a given region.

This distribution map allows a detailed appreciation of the modalities of millstone circulation during Antiquity. The rocks were selected according to their mechanical properties, but also according to their accessibility and marketing facilities. Here, the lack of navigable waterways close to the quarries (the Oise river is not navigable at its source), the vicinity of the main road axis Reims-Bavay and the distribution pattern of the products, confirm a commercial circuit preferentially following the road networks of northern Gaul.

However before the industrial era and despite this observation, transport over land was rather long and expensive, and the price of a quern probably doubled every $110 \mathrm{~km}$ (Béal, 1996). More profitable was the transport by inland waterways and by sea, which enabled to exceed the regional scale. If five days were necessary to reach $100 \mathrm{~km}$ by road, the river transport, for example downstream following the rivers Sambre and Meuse, would have allowed to travel the same distance in one day and to carry much heavier freight (Fronteau et al., 2014).

Concerning the Macquenoise sandstone, the high level of demand north of the quarries in a region lacking good quality rocks for quern manufacturing, probably explains the northern direction taken by this scattering and the extensive distribution not exceeding $100 \mathrm{~km}$.

For longer distances, the rock is less well-represented and it reaches only the biggest markets that were well served by the main trade networks and that attracted goods from long distance (e.g. Amiens, Reims and Meaux - Fig. 13).

This distribution map furthermore allows us to exclude Devonian sandstones of the Stavelot-Venn inlier, from the Roman quern and millstone trade system. These rocks would be too close to the Eifel quarries to take over its place in this economic pattern. Therefore, it's not really the distance, but especially the travel time that must be considered, as well as the competition between the different production districts.

Future work of our research group will hopefully extend the current chronology taken into consideration and will provide new insights in the pre- and post-roman raw materials exploitation.

\section{Conclusions}

The Macquenoise quarries did not arouse much interest since the end of the $19^{\text {th }}$ century. Yet querns and millstones produced in this district during Roman times are observed throughout the provinces of Gallia Belgica and Germania inferior, a region that covers today the neighbouring regions of northern France, Belgium, Grand Duchy of Luxembourg, southern Netherlands and western Germany.

Today, thanks to a fruitful collaboration between geologists and archaeologists and with the help of new data provided by modern preventive archaeology, a specific Gallo-Roman millstone production can be related to its manufacturing centre. The petrographic characterization of the rock proves the unique geological origin of the milling stones and allows us to pinpoint the Hirson/Macquenoise district as the true epicentre of their distribution, within a large Lochkovian outcrop. This result enables also the reconstruction of the networks that ruled the trade of heavy materials during Antiquity. Therefore, it completes our vision of Ancient economy from an international point of view.

The antique millstone quarries of Macquenoise are historically important for having fed a sizeable part of the population of Gallia and Germania over several centuries. At least for this reason, they represent an important geological and cultural heritage in Belgium and northern France.

\section{Acknowledgements}

Many thanks to the Universities of Lille and Gent for their support to transnational research by funding our PhD's (P.P. and S.R.). This interest aims to open up new lines of investigation for the reconstruction of the ancient economy.

Thanks to the members of the French Millstone study group (Groupe Meule: https://groupemeule.hypotheses.org) for the registration and drawing of the querns and millstones found in the Champagne-Ardenne region and their presentation at the international conference held in Reims (France): Les meules à grain du Néolithique à l'Epoque Médiévale, technique, culture, diffusion. Archaeology - History of technics, 15 - 17 may 2014 (org. and eds: O. Buchsenschutz, G. Fronteau, S. LepareuxCouturier).

We greatly appreciated the constructive reviews of Michiel Dusar, Michel Hennebert and Luc Jacottey, allowing clarification and improvement of our manuscript.

\section{References}

Anderson, T., Agustoni, C., Duvauchelle, A., Serneels, V. \& Castella, D., 2003. Des artisans à la campagne : carrière de meules, forge et voie gallo-romaine à Châbles (FR). Academic Press Fribourg, Fribourg, Collection Archéologie Fribourgeoise, 19, 391 p.

Asselberghs, E., 1946. L'Eodévonien de l'Ardenne et des régions voisines. Mémoires de l'Institut géologique de l'Université de Louvain, 14 $598 \mathrm{p}$.

Asselberghs, E., 1954. L'Eodévonien de l'Ardenne. In Fourmarier, P. (ed.), Prodrome d'une description géologique de la Belgique. Société géologique de Belgique, Liège, 83-116.

Baatz, D., 1995. Die Wassermühle bei Vitruv X, 5, 2. Saalburg Jahrbuch, $48,5-18$.

Béal, J.-C., 1996. Pistor et Matériarius, à propos d'une stèle funéraire de Metz antique. Revue archéologique de l'Est, 47, 79-95.

Boyer, F. \& Fronteau, G., 2011. Les géomatériaux meuliers : de l'identification des sources géologiques à la définition de catégories de gisements. In Buchsenschutz, O., Jaccottey, L. \& Blanchard, J.-L. (eds), Évolution typologique et technique des meules du Néolithique à l'an mille sur le territoire français, actes des IIIe rencontres de 1'Archéosite gaulois. Aquitania supplément 23. Fédération Aquitania, Bordeaux, 121-135.

Berrocal-Rangel, L., Garcia-Gimenez, R., Manglano, G.R. \& Ruano, L., 2016. When archaeological context is lacking. Lithology and spatial analysis, new interpretations of the "verracos" Iron Age sculptures in Western Iberian Peninsula. Journal of Archaeological Science: Reports, in press. https://doi.org/10.1016/j.jasrep.2016.03.031

Brulet, R., 1982-1985. Établissement gallo-romain à Macquenoise : thermes et centre sidérurgique. Documents et rapports de la Société paléontologique et archéologique de l'arrondissement judiciaire de Charleroi, 59, 27-55.

Buchsenschutz, O., Fronteau, G., Jaccottey, L., Jodry, F. \& Saurel, M., 2017. Les meules gauloises d'Acy-Romance (Ardennes), La Warde. In Buchsenschutz, O., Fronteau, G., Jaccottey, L. \& LepareuxCouturier, S. (eds), Les meules à grain du Néolithique à l'Époque Médiévale : technique, culture, diffusion, Actes du 2e colloque du Groupe Meule, Reims du 15 au 17 mai 2014. Revue Archéologique de 1'Est, supplément 43. Société Archéologique de 1'Est, Dijon, $117-134$.

Bultynck, P. \& Dejonghe L. 2001. Devonian lithostratigraphic units (Belgium). Geologica Belgica, 4/1, 39-69.

Cattelain, L., 2015-2016. Les coffres funéraires monolithiques en Grès de Macquenoise (Momignies, province de Hainaut, Belgique). ArchéoSitula, 35, 129-138.

Chambon, R., 1954. La trouée de l'Oise avant et pendant la domination romaine. Documents et rapports de la Société royale paléontologique et archéologique de l'arrondissement judiciaire de Charleroi, 49, $1-64$. 
Clarkson, C. \& Bellas, A., 2014. Mapping stone: using GIS spatial modelling to predict lithic source zones. Journal of Archaeological Science, 46, 324-333. https://doi.org/10.1016/j.jas.2014.03.035

Cnudde, V., Dewanckele, J., De Kock, T., Boone, M., Baele, J.-M., Crombé, P., Robinson, E., 2013. Preliminary structural and chemical study of two quartzite varieties from the same geological formation: a first step in the sourcing of quartzites utilized during the Mesolithic in northwest Europe. Geologica Belgica, 16/1-2, 27-34.

Corteel, C., Van den haute, P. \& Verniers, J., 2004. New sedimentological and petrographical observations on the Devonian Burnot Formation in the Belgian Rhenohercynian Basin. Geologica Belgica, 7/1-2, 41-53.

Deflorenne, A., 1973. Le Château de Macquenoise et le camp d'arkose, synthèse de documents archéologiques et historiques sur la région de Macquenoise. Cercle archéologique et historique de la Thiérache, Vervins, $56 \mathrm{p}$

Dejonghe, L., Colbach, R. \& Goemaere, E., 2017. The lithostratigraphy of the lower Devonian formations of the Eisleck region (northern Luxembourg). Comparison with their Belgian lateral equivalents. Geologica Belgica, 20/1-2, 33-42. http://dx.doi.org/10.20341/ gb.2017.001

De Kock, T., Dumon, M., Lanzon, M., Verbrugge, A., Van Ranst, E., Crombé, Ph., Cnudde, V., 2015. Mineralogical transformations in sandstone: a fingerprint for prehistorical heating of Palaeolithic hearth stones. European Journal of Mineralogy 27/5, 651-657. https://doi.org/10.1127/ejm/2015/0027-2468

Delgado-Raack, S., Gómez-Gras, D. \& Risch, R., 2009. The mechanical properties of macrolithic artifacts: a methodological background for functional analysis. Journal of Archaeological Science, 36/9, 18231831. https://doi.org/10.1016/j.jas.2009.03.033

Desmasures, A., 1883. Histoire de Saint-Michel-en-Thiérache, tome 1. Ed. du Chertemps, Hirson, 202 p. (facsimile 1984).

D’Otreppe, H., 1994. Des «meules» ovoïdes près de Schlommefurt (Saint-Vith). Glain et Salm Haute Ardenne, 41, 94-95.

Dreesen, R., Coquelet, C., Creemers, G., De Clercq, W., Fronteau, G., Gluhak, T. M., Hartoch, E., Henrich, P., Lafitte, J.-D., Picavet, P., Reniere, S., Ruppiene, V., Thiebaux, A., Vanderhoeven, A., Vynckier, G. \& Goemaere, E., 2014. Unraveling geological and geographical provenances of lithic materials during Roman times in Belgium: a fruitful collaboration between geologists and archaeologists. European Geologist, 38, 14-20.

Dumont, A.H., 1848. Mémoire sur les Terrains Ardennais et Rhénan de l'Ardenne, du Rhin, du Brabant et du Condros. Mémoires de l'Académie Royale des Sciences, des Lettres et des Beaux-Arts de Belgique, 22, $451 \mathrm{p}$.

Farget, V. \& Fronteau, G., 2011. Les carrières de meules des Fossottes, La Salle (Vosges). In Buchsenschutz, O., Jaccottey, L. \& Blanchard, J.-L. (eds), Évolution typologique et technique des meules du Néolithique à l'an mille sur le territoire français, actes des IIIe rencontres de 1'Archéosite gaulois. Aquitania supplément 23. Fédération Aquitania, Bordeaux, 137-145.

Fieremans, M. \& De Paepe, P., 1982. Genesis of tourmalinites from Belgium: petrographical and chemical evidence. Mineralogical Magazine, 46, 95-102.

Fronteau, G., Turmel, A., Pichard, C., Decrock, B., Devos, A., Lejeune, O., Menival, D., Chalumeau, L. \& Combaud, A., 2014. Les approvisionnements en pierre de construction à Reims : des choix marqués par de fortes contraintes géologiques, géographiques et socio-économiques. In Lorenz, J., Blary, F. \& Gély, J.-P. (eds), Histoire urbaine de la pierre à bâtir, actes du $137 \mathrm{e}$ congrès national du CTHS : 23-28 avril 2012 (Tours). Comité des Travaux Historiques et Scientifiques, Paris, 235-250.

Garcia, D. \& Meeks, D. (eds), 1997. Techniques et économie antiques et médiévales : le temps de l'innovation, Actes du colloque d'Aixen-Provence (21-23 mai 1996). Collection Archéologie aujourd'hui, Errance, Paris, 239 p.

Gluhak, T.M. \& Hofmeister, W., 2009. Roman lava quarries in the Eifel region (Germany): geochemical data for millstone provenance studies. Journal of Archaeological Science, 36, 1774-1782. https:// doi.org/10.1016/j.jas.2009.04.007

Gluhak, T.M. \& Hofmeister, W., 2011. Geochemical provenance analyses of Roman lava millstones north of the Alps: a study of their distribution and implications for the beginning of Roman lava quarrying in the Eifel region (Germany). Journal of Archaeological Science, 38, 1603-1620. https://doi.org/10.1016/j.jas.2011.02.025
Gomart, L., Hachem, L., Hamon, C., Giligny, F. \& Ilett, M., 2015. Household integration in Neolithic villages: A new model for the Linear Pottery Culture in west-central Europe. Journal of Anthropological Archaeology, 40, 230-249. https://doi.org/10.1016/j. jaa.2015.08.003

Gosselet, J., 1883a. Note sur 1'Arkose d'Haybes et du Franc-Bois de Willerzie. Annales de la Société Géologique du Nord, 10, 194-205.

Gosselet, J., 1883b. Note sur le Bassin de 1'Ardenne et sur les Arkoses métamorphiques. Bulletin de la Société géologique de France, 11/3, 662.

Gosselet., J., 1888. L'Ardenne, mémoires pour servir à l'explication de la carte géologique détaillée de la France. Baudry \& Cie, Paris, 881 p.

Grailet, L., 2003. L'exploitation des meules au sud du plateau fagnard. Hautes Fagnes, 3, 73-80.

Guettard, J.E., 1780. Atlas et description minéralogique de la France, entreprise par ordre du roi par MM Guettard et Monnet, publiés par M. Monnet d'après les nouveaux voyages. Première partie. Ed. Didot l'ainé, Desnos, Jombert jeune, Paris, 214 p.

Guillier, G., Biard, M. \& Cherel, A.-F., 2005. Un atelier augustéen de taille de meules en poudingue au "Clos des Forges" à Avrilly (Eure). Revue Archéologique de 1'Ouest, 22, 199-220. http://dx.doi. org/10.3406/rao.2005.1123

Hamon, C., 2008. Functional analysis of stone grinding and polishing tools from the earliest Neolithic of north-western Europe. Journal of Archaeological Science, 35/6, 1502-1520. https://doi.org/10.1016/j. jas.2007.10.017

Hartoch, E. (ed.), Doperé, F., Dreesen, R., Gluhak, T., Goemaere, E., Manteleers, I., Van Camp, L. \& Wefers, S., 2015. Moudre au Pays des Tungri. Atuatuca, 7. Publications of the Gallo-Roman Museum, Tongeren, $412 \mathrm{p}$.

Jaccottey, L. \& Milleville, A., 2010. Aux origines de la meule : premiers exemples de carrières de moulins de type «va-et-vient», Massif de la Serre, Jura. In Beeching, A., Thibault, E., Vital, J. (eds), Économie et Société à la fin de la Préhistoire, actualité de la recherche, actes des 7 e Rencontres méridionales de Préhistoire récente tenues à Bron (Rhône) les 3 et 4 novembre 2006. Documents d'Archéologie en Rhône-Alpes et en Auvergne, 34, Lyon, 109-123.

Jaccottey, L., Farget, V., Fronteau, G., Maerten, M., Beuchot, S., 2011. Le site du Portus à Collonge-en-Charollais (Saône-et-Loire), exemple d'une chaîne opératoire de fabrication de moulins rotatifs antiques. In Buchsenschutz, O., Jaccottey, L., Jodry, F., Blanchard, J.L., (eds), Évolution typologique et technique des meules du Néolithique à l'an mille sur le territoire français. Table-ronde de Saint-Juliensur-Garonne (F) du 2 au 4 octobre 2009. Aquitania supplément 23. Fédération Aquitania, Bordeaux, 163-197.

Jaccottey, L., Alonso, N., Defressigne, S., Hamon, C., LepareuxCouturier, S., Brisotto, V., Galland-Crety, S., Jodry, F., Lagadec, J.-P., Lepaumier, H., Longepierre, S., Milleville, A., Robin, B., Zaour, N., 2013. Le passage des meules va-et-vient aux meules rotatives en France. In Rausz, S., Colin, A., Gruel, K., Ralston, I., Dechezlepretre, T. (eds), L'âge du Fer en Europe. Mélanges offerts à O. Buchsenschutz. Mémoires Ausonius, 32. Ausonius Ed., Bordeaux, 405-419.

Jottrand, G., 1886. Les excavations romaines nommées le Camp de Macquenoise. Documents et rapports de la Société Royale d'Archéologie et de Paléontologie de l'arrondissement judiciaire de Charleroi, 18, 240-247.

Jottrand, G., 1895. L'industrie de la fabrication des meules en Belgique avant et après la conquête romaine. Bulletin de la Société Anthropologique de Bruxelles, 13, 390-408.

Jottrand, G. \& Cumont, F., 1901. Assemblée générale du 8 mai 1901. Annales de l'Institut Archéologique du Luxembourg, 36, 29-31.

Kaisin, F., 1908. Les caractères lithologiques de l'arkose de Dave. Bulletin de la Société belge de Géologie, Paléontologie et Hydrologie, 22, 231-239.

Lejeune, P., 1979. Trois meules (ou broyeurs) préhistoriques à Neuville (Vielsalm). Archéologie, 1, 16.

Longepierre, S., 2012. Meules, moulins et meulières en Gaule méridionale du IIe s. avant J.-C. au VIIe s. après J.-C, Monographies Instrumentum, 41. Éd. Monique Mergoil, Montagnac, France, 569 p.

Maillieux, E., 1927. Étude du Dévonien du bord sud du bassin de Dinant. Le Dévonien des environs de Couvin. In Asselberghs E. \& Maillieux E., Comptes rendus de la 5ème session extraordinaire de la Société Géologique et Minéralogique de Bretagne tenue dans le terrain dévonien de l'Ardenne, entre Charleville et Gembloux. Bulletin de la Société géologique et Minéralogique de Bretagne, 6, 128-168. 
Meilliez, F., 1984. La Formation de Fépin (Gedinnien de l'Ardenne): un marqueur régional lithostratigraphique et structural. Annales de la Société Géologique du Nord, 103/1, 37-53.

Meilliez, F., 2006. La discordance éodévonienne de l'Ardenne : caractérisation stratigraphique et paléoenvironnementale de la Formation de Fépin et ses conséquences. Géologie de la France, 1-2, 29-33.

Meilliez, F. \& Blieck, A., 1994. Formation de Fépin. In Godefroid, J., Blieck, A., Bultynck, P., Dejonghe, L., Gerrienne, P., Hance, L., Meilliez, F., Stainier, P., Steemans, P., Les formations du Dévonien inférieur de la Vesdre, de la Fenêtre de Theux et du Synclinorium de Dinant (Belgique, France). Mémoires pour servir à l'explication des cartes géologiques et minières de la Belgique, 38, 23-27.

Mennesson, E., 1877. Le Camp de Macquenoise. La Thiérache, Bulletin de la Société archéologique de Vervins (Aisne), 5, 128-135.

Mennesson, E., 1880. Macquenoise. La Thiérache, Bulletin de la Société Archéologique de Vervins (Aisne), 7, 124-130.

Michot, J., 1963. Les feldspaths dans les sédiments dévoniens et carbonifères de la Belgique. Mémoires de l'Académie Royale de Belgique, Classe des Sciences, 34/1, 56 p.

Picavet, P., 2014. Mouture de subsistance, d'appoint, et artisanat alimentaire de rendement. Les meules gallo-romaines entre villes et campagnes dans le nord de la Gaule. In Deru, X. \& Gonzàlez Villaescusa, R. (eds), Consommer dans les campagnes de la Gaule romaine, Actes du Xe Congrès de l'association AGER. Revue du Nord, Coll. Art et Archéologie, Hors-série 21. Université Lille 3, Villeneuve d'Ascq, 51-65.

Picavet, P., 2017. Libramont-Chevigny/Freux : découverte d'une carrière de meules protohistorique dans le Bois de la Hè. Chronique de l'Archéologie Wallonne, 25, 139-141.

Picavet, P., Fronteau, G. \& Boyer, F., 2011. Les meules romaines de sept chefs-lieux de cité de Gaule Belgique occidentale, étude du matériel et synthèse bibliographique. Revue du Nord, 93/393, 167-226.

Picavet, P., Fronteau, G., Le Quellec, V. \& Boyer, F., 2017. Les productions de meules en grès dévonien dit « Arkose » d'Haybes/Macquenoise de la fin de l'Âge du fer à l'Antiquité tardive dans le nord de la Gaule : caractérisation typologique, chronologie et diffusion. In Buchsenschutz, O., Lepareux-Couturier, S., Fronteau, G. (eds), Les meules du Néolithique à l'Époque Médiévale : technique, culture, diffusion, Actes du 2e colloque du Groupe Meule, Reims du 15 au 17 mai 2014. Revue Archéologique de l'Est, supplément 43. Société Archéologique de l'Est, Dijon, 267-281.

Piette, A., 1847. Histoire de l'abbaye de Foigny, ordre de Citeaux, filiation de Clervaux. Papillon, Vervins, 288 p.

Renard, A.F., 1884. Notice sur la composition minéralogique de l'Arkose d'Haybes. Bulletin du Musée Royal d'Histoire Naturelle de Belgique, 3, 117-128.

Reniere, S., Dreesen, R., Fronteau, G., Gluhak, T., Goemaere, E., Hartoch, E., Picavet, P. \& De Clercq, W., 2016. Querns and mills during Roman times at the northern frontier of the Roman Empire (Belgium, northern France, southern Netherlands, western Germany): Unravelling geological and geographical provenances, a multidisciplinary research project. Journal of Lithic Studies, 3/3, 403-428. https://doi.org/10.2218/jls.v3i3.1640

Robert, B. \& Landréat, J.-L., 2005. Les meules rotatives en calcaire à glauconie grossière et l'atelier de Vauxrezis (Aisne). Un état de la question. In Auxiette, G. \& Malrain, Fr. (eds), Hommage à Claudine Pommepuy. Revue Archéologique de Picardie, n spécial 2, 105-114.

Rogine, F., 1876. Les moulins romains de la Thiérache. La Thiérache, Bulletin de la Société Archéologique de Vervins (Aisne), 4, 140-147.

Rogine, F., 1880. L'arkose de Weismes et le poudingue de Fépin dans le bois de Milourd. La Thiérache, Bulletin de la Société Archéologique de Vervins (Aisne), 7, 118-123.

Rogine, F., 1881-1882. Une dernière excursion au camp de Macquenoise. La Thiérache, Bulletin de la Société archéologique de Vervins (Aisne), 8, 197-207.

Santi, P., Renzulli, A. \& Bell III, M., 2014. The volcanic millstones from the archaeological site of Morgantina (Sicily): provenance and evolution of the milling techniques in the Mediterranean area. Archaeometry, 57/5, 803-821. https://doi.org/10.1111/arcm.12139

Thorez, J. \& Dreesen, R., 1986. A model of a regressive depositional system around the Old Red Continent as exemplified by a field trip in the Upper Famennian "Psammites du Condroz" in Belgium. Annales de la Société Géologique de Belgique, 109, 285-323.
Turmel, A., Fronteau, G., Chalumeau, L., Deroin, J.-P., Eyssautier-Chuine, S., Thomachot-Schneider, C., De Kock, T., Cnudde, V. \& Barbin, V. 2016. GIS-based variability of building materials towards the Ilede-France cuesta (Paris Basin, France): Inventory, distribution, uses and relationship with environment. In Prikryl, R., Török, A., GomezHeras, M., Miskovsky K. \& Theodoridou, M. (eds), Sustainable Use of Traditional Geomaterials in Construction Practice. Geological Society of London, Special Publications, 416, 113-131. https://doi. org/10.1144/SP416.16

Van Ranst, E., 1977. Petrografische en petrologische studie van de Arkose van Haybes in de groeve van Lahonry (Couvin, België). Natuurwetenschappelijk Tijdschrift, 59, 97-113.

Wefers, S., 2011. Still using your saddle quern? A compilation of the oldest known rotary querns in Western Europe. In Williams, D. \& Peacock, D. (eds), Bread for the People: The Archaeology of Mills and Milling. British Archaeological Reports International Series, 2274. University of Southampton, Southampton, 67-76.

Williams-Thorpe, O. \& Thorpe R.S., 1989. Provenancing and archaeology of Roman millstones from Sardinia (Italy). Oxford Journal of Archaeology, 8/1, 89-113. https://doi.org/10.1111/j.1468-0092.1989. tb00193.x
Manuscript received 05.09.2017, accepted in revised form 01.02.2018, available on line 11.04.2018. 
Annex 1. Commentary by Michot (1963) on the arkosic nature of the Arkose d'Haybes.

“On sait que l'ensemble conglomératique de base du Gedinnien est généralement connu sous l'appellation de poudingue et arkose de base (arkose de Fépin, arkose d'Haybes, arkose de Dave, arkose de Salm-Château, etc...) (J. Gosselet, 1883 b ; A. Renard, 1884 ; F. Kaisin, 1908). Le terme « arkose » employé dès les premiers levés géologiques pour désigner les roches grossières de cet ensemble, se justifiait à l'origine parce qu'on y observait de nombreux points d'altération (kaolinisation) liés, semblait-il, à la présence de feldspaths. Ces observations faites à l'échelle macroscopique n'ont pas été confirmées par celles qui plus tard ont été entreprises à l'échelle du microscope et particulièrement par celles qui ont été réalisées dans cette étude. [...] Exception faite de quelques minces niveaux, l'ensemble de base du Gedinnien ne contient pas de feldspath, et aucun reste partiellement transformé en kaolinite n'y a jusqu'à présent été découvert. De plus, dans les petits niveaux intercalaires feldspathiques et non arkosiques (moins de $10 \%$ de feldspaths), on ne décèle sur ce minéral aucun indice de ce type d'altération. Ceci semble donc exclure le feldspath comme substrat de la kaolinisation. (...) Il n'est pas justifié de conserver le terme « arkose » pour désigner les roches de base du Gedinnien.”

\section{Annex 2. The lithostratigraphic succession recognized within the Fépin Formation (FEP) by Gosselet in 1888.}

"Dans la vallée de l'Oise, entre Milourd et le Pas-Bayard, il y a d'anciennes carrières d'arkose qui peuvent donner une idée de la structure de l'assise, à sa partie inférieure. Les couches sont inclinées de 75 à 80 degrés vers le nord; elles présentent, à partir du sud :

Phyllades noirs cambriens.

Poudingue

Arkose verdâtre compacte

Arkose gris blanc en trois bancs

Schiste gris blanc en trois bancs

Arkose verte dans la masse en deux bancs

Arkose gris rose

Arkose gris blanc en cinq ou six bancs

Arkose anciennement exploitée

Arkose gris roux, rognoneuse

Schiste avec noyaux d'arkose

Arkose jaunâtre altérée à la surface du sol

$$
\begin{array}{r}
1 \text { à } 2 \mathrm{~m}, 00 \\
3 \mathrm{~m}, 00 \\
6 \mathrm{~m}, 00 \\
0 \mathrm{~m}, 40 \\
2 \mathrm{~m}, 60 \\
0 \mathrm{~m}, 30 \\
6 \mathrm{~m}, 00 \\
4 \mathrm{~m}, 00 \\
0 \mathrm{~m}, 43 \\
1 \mathrm{~m}, 00 \\
13 \mathrm{~m}, 00
\end{array}
$$

À partir de Milourd, un escarpement d'arkose borne au sud la vallée de l'Oise. Les Romains y avaient creusé plusieurs carrières qui sont maintenant presque entièrement cachées par les bois. Le prétendu camp de César de Macquenoise était un chantier où ils exploitaient et travaillaient l'arkose. On y voit encore une foule de trous remplis de meules, dont quelques-unes sont entières, mais dont la plupart sont brisées ou en cours de travail. Les antiquaires y trouvent aussi une mine inépuisable de monnaies, de statuettes et d'autres objets de l'époque." 